\title{
OBJEKTIFIKASI DAN RESILIENSI PEREMPUAN DALAM NOVEL PEREMPUAN BAYANGAN KARYA NETTY VIRGIANTINI
}

\author{
Tania Intan \\ Departemen Susastra dan Kajian Budaya, FIB, Universitas Padjadjaran \\ Jl. Raya Bandung-Sumedang Km. 21,7 Jatinangor, Jawa Barat, Indonesia \\ tania.intan@unpad.ac.id
}

\begin{abstract}
ABSTRAK: Penelitian ini bertujuan untuk mengungkap adanya objektifikasi dan resiliensi perempuan di dalam novel Perempuan Bayangan karya Netty Virgiantini. Penelitian ini dilakukan pada bulan April 2021. Metode yang digunakan dalam penelitian ini adalah deskriptif kualitatif, dengan pendekatan kritik sastra feminis. Data berupa kata, frasa, dan kalimat dari objek penelitian dipilih dengan teknik simak-catat setelah melalui pembacaan tertutup. Data kemudian diklasifikasi, diinterpretasi, dan dikaji dengan teori yang relevan. Hasil penelitian ini menunjukkan bahwa perempuan rentan mengalami objektifikasi, sebagaimana yang dialami oleh tokoh utama perempuan, Ningrum. Objektifikasi tersebut dilakukan oleh orangtua yang memaksanya untuk menikah, kedua calon mertuanya yang menolaknya karena tidak dapat memberikan keturunan, Satria yang memanfaatkannya untuk menghilangkan kesepian dan melampiaskan hasrat seksual, dan arwah Utari yang mengharapkannya menjadi istri pengganti. Tokoh perempuan tersebut menyikapi objektifikasi dengan resiliensi secara verbal dan juga dalam bentuk tindakan aktif.
\end{abstract}

KATA KUNCI: kritik sastra feminis; Netty Virgiantini, objektifikasi; perempuan; resiliensi

\section{OBJECTIVES AND WOMEN'S RESILIENCE IN NETTY VIRGIANTINI's NOVEL} PEREMPUAN BAYANGAN

\begin{abstract}
This study aims to reveal the objectification and resilience of women in the novel Perempuan Bayangan by Netty Virgiantini. This research was conducted in April 2021. The method used in this research is descriptive qualitative, with a feminist literary criticism approach. Data in the form of words, phrases, and sentences from the research object were selected using the note-taking technique after going through closed reading. The data are then classified, interpreted, and reviewed with relevant theories. The results of this study indicate that women are prone to objectification, as experienced by the main female character, Ningrum. The objectification was carried out by her parents (who forced her to marry), her two prospective parents-in-law (who rejected her because she was unable to give offspring), Satria (who used her to get rid of loneliness and indulge sexual desires), and the spirit of Utari (who expected her to become a substitute wife). The female character responds to objectification with resilience verbally and also in the form of active action.
\end{abstract}

KEYWORDS: feminist literary criticism; Netty Virgiantini, objectification; resilience; women

\begin{tabular}{llll}
\hline Diterima: & Direvisi: & Distujui: & Dipublikasi: \\
2021-06-06 & 2021-07-05 & 2021-07-07 & 2021-10-29
\end{tabular}

Pustaka : Intan, T. (2021). OBJEKTIFIKASI DAN RESILIENSI PEREMPUAN DALAM NOVEL PEREMPUAN BAYANGAN KARYA NETTY VIRGIANTINI. Fon: Jurnal Pendidikan Bahasa dan Sastra Indonesia, 17(2), 108-121. doi:https://doi.org/10.25134/fon.v17i2.4209

\section{PENDAHULUAN}

Dalam kajian Ariadi (2019), terungkap bahwa sejak tahun 2000-an, kesusastraan Indonesia mengalami dinamika dengan hadirnya sejumlah besar karya pengarang perempuan, baik yang bernilai 'sastra' maupun 'populer'. Dalam karya-karya tersebut, perempuan dan tubuhnya muncul sebagai subjek baru yang memiliki pemikiran mandiri. 
Perempuan dalam karya sastra, menurut Nurfaidah (2018: hlm. 157-158), diposisikan dalam berbagai sudut pandang, antara lain dari sudut pandang laki-laki (male gaze) seperti Nyai Dasima dan Gadis Pantai, atau dari sudut pandang perempuan (female gaze) seperti Saman dan Gelang Giok Naga. Namun, karyakarya tentang perempuan ini masih merupakan kelindan di antara permasalahan stereotipikal yang mungkin dialami perempuan, seperti pernikahan, percintaan, trauma, kekerasan, maupun kelajangan.

Perempuan lajang dengan berbagai permasalahannya juga merupakan fokus yang dipilih oleh Netty Virgiantini untuk dinarasikan dalam karya-karyanya. Pada novel Jodoh Terakhir (2016) misalnya, terungkap tema tentang perempuan lajang yang harus menerima perjodohan demi menghindari aib yang menimpa keluarga. Pada novel lainnya, Cinta Separuh Hati (2015), pengarang mengangkat tema perempuan berusia 35 tahun yang melakukan sejumlah kebohongan secara berturut-turut untuk menutupi kelajangan yang membuat dirinya tidak nyaman.

Dalam novel Perempuan Bayangan (2020) yang dipilih sebagai objek penelitian ini, terindikasi adanya fenomena objektifikasi terhadap tokoh perempuan, yang juga masih lajang di usianya yang tidak lagi remaja. Novel ini mengisahkan kerumitan yang dialami Ningrum, seorang perempuan yang tidak dapat melahirkan anak, sehingga membuatnya bersedia dijodohkan dengan Satria, laki-laki yang telah ditinggal mati istrinya. Selain dari keluarganya, dalam relasi perkawinannya pun Ningrum menghadapi berbagai perlakuan yang menjurus pada tindakan objektifikasi.

Menghadapi situasi hegemonis tersebut, ada bentuk-bentuk perlawanan dan resiliensi yang ditunjukkan oleh tokoh perempuan.
Objektifikasi pada prinsipnya, sebagaimana dinyatakan Calogero (2012: hlm. 574), adalah pandangan yang menempatkan perempuan sebagai objek seperti dalam konteks perempuan sebagai jarahan perang. Perempuan menjadi target utama objektifikasi seksual bagi laki-laki karena bentuk tubuhnya yang dianggap unik.

Nussbaum, yang dikutip Artana (2018: hlm. 1), memaparkan cara objektifikasi perempuan bekerja melalui tindak instrumentalitas, penolakan anatomi, pasif, fungsibilitas, kekerasan, kepemilikan, dan penolakan subjektifitas. Objektifikasi ini berkembang seiring dengan menguatnya ideologi patriarki dalam struktur sosial. Menurut Walby (2014), ideologi tersebut beroperasi dengan cara mentransmisikan kecenderungan praktik-praktik yang timpang gender.

Budiarti (2014: hlm. 6) mengutip Syarifah yang menyatakan bahwa objektifikasi merupakan salah satu bentuk kontrol patriarkis terhadap seksualitas perempuan. Objektifikasi terjadi jika individu melalui sarana-sarana sosial direndahkan derajatnya, dijadikan benda atau komoditas, dibeli, atau dijual.

Ketika menghadapi opresi yang mewujud pada tindak objektifikasi, perempuan dapat bersikap resilien. Menurut Glicken, yang dikutip Deborah (2018: hlm. 124), resiliensi adalah kemampuan individu untuk menahan dan bangkit kembali (bounce back) dari tantangan hidup yang mengganggunya. Dengan demikian, dapat dinyatakan bahwa individu yang resilien berarti telah mengalami kejadian yang mungkin dianggap traumatis oleh orang lain. Namun, individu tersebut dapat bertahan. Lebih jauh lagi, ia memiliki kemampuan berkembang, menjadi dewasa, dan meningkatkan kompetensi diri dalam ruang lingkup yang tidak menguntungkan dirinya tersebut. 
Dalam konteks psikologis, Schoon (2006) menjelaskan resiliensi sebagai proses dinamika yang dijalani individu yang menampilkan fungsi adaptif dalam menghadapi permasalah hidup. Permasalahan yang dimaksud menurut Schoon, di antaranya adalah faktor sosial ekonomi rendah, memiliki riwayat penganiayaan, kekurangan fisik, penyakit kronis, atau mengalami trauma. Marlia menjelaskan, melalui Pratiwi dan Hirmaningsih (2016: hlm. 69), bahwa meskipun menghadapi permasalahan berat dalam hidupnya, banyak perempuan yang mampu mempertahankan hidupnya dan menyesuaikan diri dengan keadaannya.

Penelitian terdahulu dengan tema objektifikasi perempuan dalam karya populer di antaranya telah dilakukan oleh Lahdji (2015) yang menemukan fenomena tersebut di dalam lirik lagu dangdut populer. Kajian yang menggunakan analisis wacana Sara Mills tersebut mengungkap bagaimana di dalam media itu perempuan masih [selalu] diposisikan sebagai mahluk sekunder dan menjadi objek bagi laki-laki. Penelitian lain dilakukan Artana (2018) yang menelaah objektifikasi dan abjeksi dalam novel Burial Rites karya Hannah Kent. Artana menggunakan teori objektifikasi dari Calogero dan abjeksi dari Kristeva.

Ariawan (2019) mengkaji opresi dan objektifikasi terhadap perempuan dalam film pendek Libertines karya Arwin Wardhana dengan pendekatan feminisme radikal-libertarian dari Kate Millet. Perlawanan terhadap objektifikasi yang dilakukan tokoh utama perempuan dalam film tersebut ditunjukkan dengan perubahan performativitas seksualnya menjadi androgini. Penelitian Windiyarti (2017) terhadap novel Gadis Pantai karya Pramoedya Ananta Toer memperlihatkan bahwa perempuan yang direpresentasikan oleh tokoh Gadis Pantai berpotensi mengalami marginalisasi, objektifikasi, dan kekerasan yang dipraktikkan oleh tokoh laki-laki dari kelas atas yang dipanggil 'Bendoro'. Hal ini terjadi karena struktur sosial-budaya masyarakat memfasilitasi terciptanya situasi tersebut.

Resiliensi perempuan sendiri telah diteliti, di antaranya oleh Intan dan Gumilar (2020) yang menganalisis novel Perempuan Bersampur Merah karya Intan Andaru. Dalam kajian ini, perempuan disorot berdasarkan daya sintasnya untuk bangkit melawan stigma dan trauma. Telaah mengenai perlawanan perempuan terhadap objektifikasi juga dilakukan Budiarti (2014) yang mempelajari novel The Sinden karya Halimah Munawir. Penelitian tersebut menggunakan teori standpoint, teori feminis radikal kultural, dan teori resistensi dengan pendekatan analisis semiotika naratif A.J Greimas. Hasil dari kajian ini adalah adanya bentuk perlawanan terhadap opresi laki-laki yang menempatkan perempuan sebagai objek tatapan dan objek hasrat seksualnya.

Dalam penelitian yang dilakukan Tyas (2018), terungkap adanya gejala perlawanan atas kekuasaan dan objektifikasi tubuh perempuan di dalam novel Cerita Cinta Enrico karya Ayu Utami. Kajian yang menggunakan pendekatan feminis radikal kultural ini menghasilkan rumusan simpulan bahwa gagasan feminis ditampilkan melalui kesadaran perempuan atas tubuhnya, penolakan pada pernikahan yang tidak dalam relasi setara, dan negasi atas keberadaan anak karena perempuan memiliki hak untuk bereproduksi atau menolaknya.

Dalam penelusuran peneliti, kajian atas karya-karya metropop Netty Virgiantini belum banyak ditemukan, kecuali di antaranya oleh Normuliati dan Urahmah (2015) yang mempelajari eksistensi perempuan di dalam novel Cincin Separuh Hati. Penelitian tersebut memperlihatkan bahwa eksistensi perempuan dalam novel tersebut di antaranya meliputi eksistensi dalam dunia 
sendiri, eksistensi relasi, eksistensi intensionalitas, eksistensi kesadaran. Novel Cincin Separuh Hati juga telah dikaji Intan dan Prayoga (2021) dengan berfokus pada strategi kebertahanan tokoh utama sebagai perempuan lajang. Kajian tersebut menemukan berbagai stigma yang dialami tokoh dan strateginya untuk bertahan dan keluar dari stigma tersebut. Intan (2021) juga menelaah makna kelajangan dan perjodohan dalam novel Jodoh Terakhir, yang memperlihatkan adanya resistensi dan negosiasi pada tokoh perempuan.

Dalam penelusuran yang dilakukan peneliti, belum ditemukan kajian terhadap novel Perempuan Bayangan, yang termasuk dalam terbitan baru (2020). Dengan demikian, penelitian ini dapat dilanjutkan, dengan tujuan untuk mengungkap fenomena objektifikasi dan resiliensi perempuan dalam novel Perempuan Bayangan karya Netty Virgiantini.

\section{METODE}

Penelitian ini dilakukan pada bulan April 2021. Metode yang digunakan dalam penelitian ini adalah deskriptif kualitatif, dengan pendekatan kritik sastra feminis. Pendekatan ini diaplikasikan karena karena teks yang ditelaah merupakan novel metropop yang ditulis perempuan, dibaca perempuan, dan membicarakan terutama tentang perempuan.

Wiyatmi (2012: hlm. 11) mengutip Ruthven, yang menjelaskan bahwa kritik sastra feminis bersifat revolusioner karena memiliki tujuan menumbangkan wacana dominan yang diciptakan suara tradisional dan patriarkis. Showalter, melalui Wiyatmi (2012: hlm. 30), memaparkan dua jenis kritik sastra feminis, yaitu kritik yang melihat perempuan sebagai pembaca dan kritik yang melihat perempuan sebagai penulis.
Untuk penelitian ini, akan digunakan kritik sastra yang melihat perempuan sebagai pembaca, karena kritik ini berfokus pada citra dan stereotip perempuan dalam sastra, serta pengabaian dan kesalahpahaman tentang perempuan. Perempuan dalam karya sastra hampir selalu ditempatkan sebagai korban, bersifat sentimental dan memiliki kepekaan spiritual di bawah dominansi laki-laki (Djajanegara, 2003: hlm. 7).

Sumber data untuk penelitian ini adalah novel Perempuan Bayangan (2020) karya Netty Virgiantini. Novel dengan tebal 216 halaman ini diterbitkan oleh PT. Gramedia Pustaka Utama. Karya tersebut bergenre metropop romance, yang berarti berlatar urban dengan narasi kehidupan para tokoh yang terlibat konflik percintaan.

Data berupa kata, frasa, dan kalimat yang relevan dengan tujuan penelitian dikumpulkan dari novel Perempuan Bayangan dengan teknik simak-catat setelah melalui pembacaan tertutup. Tahap analisis dimulai dengan pemaparan synopsis novel Perempuan Bayangan dan pembahasan aspek-aspek struktural karya tersebut. Selanjutnya, dilakukan pembahasan terhadap objektifikasi perempuan dalam berbagai konteks yang ditemukan di dalam novel. Pada pembahasan terakhir, diungkap bentukbentuk resiliensi perempuan dalam menghadapi objektifikasi.

\section{HASIL DAN PEMBAHASAN \\ Sinopsis dan Telaah Aspek Struktural}

Dalam novel Perempuan Bayangan, cerita dengan latar tempat kota Semarang ini terpusat pada tokoh utama Ningrum yang telah berusia tiga puluh tahun dan divonis tidak dapat memiliki keturunan. Ketika SMA, ia mengalami masalah dalam rahim sehingga harus dioperasi. Setelah dua kali berpacaran, Ningrum selalu ditolak oleh para calon mertuanya. Ia pun merasa sedih karena tidak dapat 
membahagiakan orangtuanya yang ingin melihat anak perempuan mereka satusatunya itu menikah.

Sahabat Ningrum, Padmi, kemudian menjodohkannya dengan Satria, sepupunya yang masih berduka sejak kepergian istrinya tiga tahun yang lalu. Satria berjanji untuk setia pada istrinya yang telah tiada itu, tapi tidak dapat menolak tawaran Padmi untuk mengenalkannya pada Ningrum. Demi kepentingan masing-masing, Satria dan Ningrum pun bertemu, belajar saling mengenal, dan tidak lama kemudian menikah.

Tinggal bersama di rumah Satria tidak otomatis menciptakan kebahagiaan pada diri Ningrum maupun Satria sendiri. Hingga suatu saat, keduanya menyadari bahwa mereka mulai saling menyayangi dan takut kehilangan satu sama lain.

Alur cerita bergerak secara progresif dan cepat, dimulai dari kondisi Ningrum yang terpuruk, perjodohannya dengan Satria, pernikahan mereka, dan kehidupan rumah tangga yang hambar setelahnya. Namun ada beberapa sekuen flash back yang merupakan bagian penjelas dari situasi yang sedang dikisahkan, seperti tentang saat kematian Utari yang membuat Satria sangat terpukul.

Tokoh utama novel Perempuan Bayangan adalah Prawitaningrum, atau biasa dipanggil Ningrum, memiliki karakter yang santai, gemar bercanda, dan seperti tidak pernah tersinggung (hlm. 119). Ia senang mendengarkan lagu dangdut koplo sejak mengalami patah hati yang kedua kali. Ningrum berpendidikan sarjana dan bekerja sebagai karyawan administrasi di perusahaan yang sama dengan Padmi. Ia divonis tidak dapat memiliki anak karena rahimnya telah diangkat. Realita ini pun membuatnya sempat berpikir untuk tidak menikah selamanya.

Satria telah menduda selama 3 tahun. Karena sangat mencintai Utari, ia tidak dapat berpaling pada perempuan lain. Ia bahkan berjanji untuk selalu mencintai Utari di depan jasadnya. Ketika telah menikah dengan Ningrum, ia masih selalu mengingat Utari dan membandingkan istri yang baru dinikahinya dengan perempuan yang telah meninggal itu.

Utari adalah istri Satria yang meninggal tiga tahun lalu karena serangan jantung ketika sedang hamil 4 bulan. Dalam konteks judul novel, dapat diperkirakan bahwa Utarilah yang merupakan 'Perempuan Bayangan', karena meskipun telah tiada, bayangbayangnya tidak pernah lepas dari kehidupan Satria [dan kemudian Ningrum]. Utari dikisahkan selalu membayangi pasangan tersebut meskipun tanpa maksud jahat. Sebaliknya, ia mengharapkan kebahagiaan Satria dan Ningrum agar dirinya dapat pergi dengan tenang menyusul putranya.

Tokoh pendukung yang penting dalam novel ini adalah Padmi yang merupakan sahabat Ningrum dan sepupu Satria. Padmi diceritakan telah menikah dan memiliki satu anak.

Kisah ini melibatkan dunia supranatural yang ditunjukkan oleh keberadaan dan peran tokoh Utari yang telah meninggal namun turut menggulirkan cerita. Mistisisme yang relatif mewarnai novel Perempuan Bayangan ini tidak memberi kesan menakutkan, bahkan sebaliknya, membawa atmosfer yang mengharukan terutama pada penggambaran adegan Utari yang sedih saat mendengar suara tangisan anaknya dari lingkaran cahaya.

Latar tempat yang dominan ditampilkan dalam novel Perempuan Bayangan adalah rumah tempat tinggal Satria dengan Utari, dan kemudian dengan Ningrum. Hal ini memperlihatkan kuatnya ideologi patriarki yang disosialisasikan pengarang, bahwa perempuan bertanggung jawab atas fungsi dan wilayah domestik. Meskipun tokoh 
Ningrum ditampilkan sebagai perempuan bekerja, namun hal itu bersifat komplementer dan ia bukan pencari nafkah utama. Rumah dianggap sebagai tempat yang tepat untuk perempuan dibandingkan kantor atau pabrik tempat tokoh itu bekerja.

Sudut pandang novel ini berasal dari narator di luar cerita, namun, satu peristiwa dapat dikisahkan seolah-olah melalui perspektif tiga tokoh, yaitu Ningrum, Satria, dan Utari. Sebagai contoh, pada bagian awal cerita ditampilkan perasaan ketiga tokoh tersebut saat memandang foto pernikahan Satria dan Utari yang masih terpasang di ruang tamu. Saat itu, Satria dan Ningrum telah hidup bersama selama enam bulan.

Ningrum tidak membenci foto pernikahan yang tidak boleh dipindahkan tersebut, namun ia merasa sesak karena mulai merasa mencintai Satria. Ningrum mengakui dirinya tidak dapat menggantikan Utari di hati laki-laki itu.

Namun, untuk pertama kalinya Ningrum dikejutkan rasa yang menyelinap begitu saja di benaknya. Menyentak tanpa bisa ia kendalikan. Ketika baru pulang kerja dan membuka pintu, seperti biasa pandangannya langsung terpaut pada bingkai foto yang terletak lurus dengan posisi pintu. Saat itulah seolah ada sulur-sulur bergerak cepat membelit rongga dadanya. Menyesakkan napasnya. Ada semacam kemarahan dan keinginan kuat untuk menurunkan foto itu. Menyingkirkannya.

(Virgiantini, 2020: hlm. 6)

Dalam kutipan tersebut, terungkap bagaimana narator menyuarakan perasaan tokoh Ningrum yang tidak berdaya menghadapi kehadiran perempuan lain dalam hidup suaminya. Dari sudut pandang Satria, foto tersebut sangat penting karena selalu mengingatkannya pada istri pertama. Ia sendiri tidak berkuasa menurunkan foto tersebut karena hal itu akan membuatnya merasa bersalah. Selama tiga tahun sepeninggal Utari, lakilaki itu tidak pernah memindahkan foto tersebut ke mana pun.

Namun, untuk pertama kalinya Satria dikejutkan oleh satu rasa serupa sengatan listrik 1000 watt. Kakinya yang sudah mau melangkah terhenti di depan pintu. Terpaku. Sepasang matanya melebar saking terkejutnya. Kenapa wajah perempuan di foto itu sekarang berbeda?

Sosok dan kebaya yang dikenakannya masih sama. Hanya raut wajahnya saja yang berubah.

(Virgiantini, 2020: hlm. 9)

Narator yang mahatahu dengan leluasa menguraikan isi hati tokoh lakilaki dan perasaannya yang mulai tertarik pada Ningrum. Halusinasi peralihan wajah Utari menjadi Ningrum dalam foto memperlihatkan hal tersebut. Sementara itu, (arwah) Utari yang masih menetap di rumah itu pun juga berperan sebagai pengamat perkembangan hubungan antara Ningrum dan Satria. Ia tidak merasa cemburu pada istri baru suaminya itu, dan sebaliknya, selalu mendukung agar keduanya hidup bahagia.

Biasanya Ningrum memandangnya sekilas sambil berjalan masuk melintasi ruang tamu. Tapi kali ini, langkahnya terhenti dan memandangnya cukup lama.

Ada apa dengannya? Kenapa wajahnya tampak berbeda?

(Virgiantini, 2020: hlm. 12)

Arwah Utari tertahan di rumah tersebut selama tiga tahun karena selama itu pula, Satria tidak benar-benar merelakannya pergi. Perempuan ini ingin 
segera menyusul putranya yang telah berada di dalam lingkaran cahaya dan selalu memanggil-manggilnya.

Saat itulah tiba-tiba cahaya itu muncul. Terlihat samar-samar. Tak begitu jelas. Serupa kabut tipis yang melayang di atas, menembus plafon rumah. Utari mencoba berkedip beberapa kali untuk meyakinkan pandangannya. Setitik harapan bersemi begitu melihat samar-samar cahaya itu masih ada. Ia terus berdiri menatapnya dengan air mata mengalir di pipunya.

(Virgiantini, 2020: hlm. 100)

Penggunaan multisudut pandang ini dapat memberi informasi baru dan lebih menarik, berbeda dengan bila narasi hanya berasal dari satu pencerita saja. Keberadaan beberapa narator seperti ini memungkinkan pembaca mendapatkan gambaran utuh dari suatu peristiwa.

Sifat penceritaan seperti ini juga membuat pembaca dapat memahami halhal yang tidak diketahui oleh setiap tokoh. Sebagai contoh, Padma yang hendak menjodohkan Ningrum dan Satria menyatakan hal yang berbeda pada masing-masingnya. Kepada Ningrum, Padmi bercerita bahwa Satria mengalami stres ditinggalkan oleh istri dan calon bayi mereka. Kepada Satria, Padmi menyatakan Ningrum mengalami depresi karena dua kali batal menikah. Pada kenyataannya, kedua situasi tersebut tidak benar-benar terjadi, namun kebohongan itu terbukti efektif dapat membuat kedua tokoh menjadi saling mengasihani dan mendekat satu pada yang lainnya.

Satu peristiwa disampaikan melalui sudut pandang berbeda juga ditampilkan ketika Ningrum merasa sedih karena tidak dihubungi oleh Satria selama seharian ketika dirinya lembur (hlm. 91). Kesedihan yang sama juga ternyata dirasakan oleh Satria (hlm. 96) yang menunggu-nunggu kontak dari Ningrum. Kedua tokoh ini pun mengisahkan dengan cara pandang masing-masing tentang hubungan seksual mereka untuk pertama kalinya (hlm. 111 dan 117). Peristiwa Ningrum menjatuhkan pigura foto Satria dan Utari pun dikisahkan dengan gaya dan kesan berbeda keduanya (hlm. 159 dan 166).

Dari ringkasan cerita dan pembahasan singkat terhadap aspek-aspek pembentuk karya seperti alur, tokoh, latar, dan sudut pandang ini dapat dipahami posisi dan peran tokoh utama Ningrum. Analisis tentang objektifikasi perempuan dan resiliensinya akan dilakukan pada bagian selanjutnya.

\section{Objektifikasi Perempuan dalam Berbagai Konteks}

Ningrum mengalami objektifikasi pertama dari orangtuanya yang berharap anak perempuannya itu segera menikah. Perempuan dewasa yang masih lajang, meskipun dalam konteks warga kota besar, selalu menjadi objek kecemasan keluarga dan terkadang bahkan dianggap aib.

Hanya satu hal yang terasa agak mengganjal di hatinya, karena ia tahu, orangtuanya masih mengharapkannya menikah. Yah, Namanya punya anak perempuan, satu-satunya lagi, pastilah orangtua ingin sekali bisa menggelar upacara pernikahan.

(Virgiantini, 2020: hlm. 21)

Namun, untuk mewujudkan keinginan orangtuanya tersebut tidak mudah karena Ningrum berbeda dengan perempuan kebanyakan. Ia mengalami dua kali penolakan dari calon mertua karena tidak akan dapat melahirkan anak. Yang lebih menyedihkan, kedua pacar Ningrum sama sekali tidak menunjukkan pembelaan. Dalam situasi ini, tubuh perempuan 
seperti direduksi nilainya menjadi semacam 'pabrik anak', yang bila pabrik itu tidak berfungsi maka akan dianggap tidak memiliki nilai. Perempuan mandul akan dianggap sebagai barang cacat yang tidak layak dijual.

"Kamu lupa ceritaku ketika ditolak dua calon mertua begitu tahu kondisiku? Mereka bilang, tujuan utama pernikahan itu untuk memperoleh keturunan, jadi buat apa menikahi perempuan yang jelas-jelas nggak bisa ngasih keturunan? Gabuk, mereka bilang. Dan dua laki-laki yang pernah sangat kucintai justru langsung menyetujui pendapat orangtuanya."

(Virgiantini, 2020: hlm. 20)

Bentuk objektifikasi tersebut dalam pandangan Nussbaum (2018) adalah penolakan anatomi. Tubuh perempuan dalam konstruksi patriarki merupakan tempat untuk memproduksi anak. Dengan demikian, jika fungsi tersebut tidak terpenuhi, maka perempuan tersebut dinilai tidak cukup berharga untuk dinikahi.

Objektifikasi yang juga terjadi dalam konteks Nussbaum (2018) di sini adalah berbentuk fungsional, artinya perempuan dianggap tidak memiliki fungsi atau kegunaan selain sebagai pabrik yang menghasilkan produk berupa anak. Bila mandul, maka perempuan dianggap rusak atau cacat.

Setelah menikah dan tinggal bersama, Satria melarang Ningrum memindahkan barang di rumahnya karena semua telah ditata sesuai dengan keinginan istrinya dulu. Tindakan laki-laki tersebut menjurus pada penolakan subjektifitas perempuan untuk mempertahankan posisinya sebagai pihak dominan.

Satria sudah mewanti-wanti sebelumnya supaya Ningrum tidak mengubah atau menggeser apa pun yang ada di dalam rumahnya. Dengan satu alasan yang sangat bisa dimaklumi, karena Satria ingin semua perabot dan suasana di rumah tidak berubah dari waktu terakhir almarhumah istrinya masih bersamanya.

(Virgiantini, 2020: hlm. 64)

Aturan-aturan yang dibuat Satria dan harus dipatuhi Ningrum tersebut tidak lain merupakan sistem opresi dan objektifikasi yang dipaksakan padanya. Pakaian Ningrum juga tidak boleh diletakkan di lemari kamar karena di sana masih ada pakaian Utari yang terawat dengan baik. Satria juga selalu membandingkan Ningrum dengan Utari, mulai dari cara membuat teh, kebiasaan ditemani saat ke kamar mandi, dan memasak.

"Nggak perlu diantar? Biasanya Utari kalau malam-malam ke kamar mandi pasti minta diantar," kata Satria dengan tatapan tertuju pada foto di meja rias samping tempat tidur.

Eyasalaaam ... orang lagi kebelet malah harus dengerin romantisme masa lalu begini.

(Virgiantini, 2020: hlm. 107)

Ningrum yang berkarakter santai mencoba untuk memahami kondisi tersebut. Ia mengekspresikan ketidaksukaannya hanya di dalam hati seperti ditunjukkan pada kutipan tersebut: "Eyasalaaam ... orang lagi kebelet malah harus dengerin romantisme masa lalu begini". Ningrum juga berusaha mengondisikan diri untuk tidak berkeberatan ketika berhubungan seksual dengan Satria, dan laki-laki itu justru menyebutkan nama Utari.

Akhirnya laki-laki itu menunduk, bergerak mendekat, hingga Ningrum 
bisa merasakan embusan napasnya. [...] Sesaat sebelum bibir Satria menyentuh perlahan bibirnya yang masih ternganga, sebuah nama meluncur dari bibir laki-laki itu, "Utari ..."

(Virgiantini, 2020: hlm. 110)

Sebenarnya, dari rutinitas malam di tempat tidur inilah mulai muncul kegelisahan di hati Ningrum. Semakin lama ia mulai menikmati pelukan dan sentuhan Satria. [...] Meski di saatsaat yang terasa melegakan sekaligus penuh kenikmatan itu, Satria selalu menyebut nama almarhumah istrinya. (Virgiantini, 2020: hlm. 130)

Kedua kutipan tersebut membuktikan bagaimana objektifikasi yang dilakukan sang suami bekerja atas diri Ningrum. Meskipun tidak, atau belum dilandasi perasaan cinta, sebagai laki-laki normal, Satria merasa dirinya dapat menyalurkan hasrat pada istrinya yang sah, Ningrum. Sebagai subjek, ia merasa memiliki keleluasaan untuk berkuasa atas tubuh objeknya, Ningrum. Objektifikasi yang terjadi dalam situasi tersebut disebut Nussbaum (2018) sebagai instrumentalitas, dalam arti laki-laki memanfaatkan perempuan yang ada di hadapannya sebagai instrumen atau alat pengingatnya pada perempuan lain.

Menurut pendapat umum, laki-laki tak perlu memusingkan perasaan saat melakukannya, cukup ikuti nafsu saja. Tapi, ia belum pernah melakukannya dengan perempuan lain selain Utari. Bahkan sepeninggal Utari, saat Satria terpaksa melampiaskan hasratnya sendiri, ia selalu membayangkan Utari saat melakukannya.

(Virgiantini, 2020: hlm. 73)
Selain Ningrum, dalam konteks nonseksual, Utari pun diobjektifikasi oleh Satria. Tanpa disadari, egoismenya sebagai laki-laki menjadikan istrinya itu sebagai objek pelampiasan kesedihan. Satria yang tidak rela istrinya pergi, bertahan dengan 'mengikat' sang arwah untuk tetap di dunia. Objektifikasi yang terjadi dalam situasi ini dapat disebut Nussbaum (2018) berkaitan dengan kepemilikan. Satria mengatribusi Utari yang telah meninggal sebagai miliknya yang tidak boleh pergi hingga ia merelakannya.

Di ruang di mana tubuhnya sudah tertutup kain dari ujung rambut sampai ujung kaki, dilihatnya Satria menangis sambil memeluk erat tubuhnya. Ia berteriak minta tolong pada suaminya, tapi ternyata tangisan dan tetesan air mata yang jatuh membasahi jasadnya telah mewujud sepasang tangan yang terus mencengkeram kakinya.

"Lepaskan, Mas. Tolong. Biarkan aku pergi ..." pintanya tepat di telinga suaminya sambil memeluk erat tubuh yang berguncang karena tangisan itu.

(Virgiantini, 2020: hlm. 98 - 99)

Ketidakrelaan Satria atas perginya Utari sebagai objek, membuat sang istri tidak tenang dan terikat pada dunia yang fana. Ia terperangkap dan melayanglayang di dalam rumah itu akibat keegoisan sang suami.

Selain melalui aturan-aturan, superioritas Satria sebagai pemilik semua hal yang ada di dalam rumah tangganya ditunjukkan pula melalui panggilan. Meskipun dengan nada bercanda, Ningrum merasa perlu menyebut Satria sebagai 'bosku' (hlm. 102), 'juragan' (hlm. 103), atau 'dewan juri' (hlm. 120), tanpa sekalipun laki-laki itu menyebut istrinya dengan panggilan yang sama. 
Situasi ini menyiratkan bahwa adanya isu ketidaksetaraan di dalam relasi mereka dan ketimpangan pembagian peran dalam rumah tangga. Sebagai istri, Ningrum, mau tidak mau memosisikan dirinya sebagai subordinat dan menunjukkan kerelaan untuk diobjektifikasi.

Perilaku opresif dan tidak menyenangkan dari sang suami sebagai pihak dominan ditunjukkan misalnya saat Ningrum membuatkan teh manis untuk Satria (hlm. 101). Laki-laki ini, alih-alih berterima kasih dan melakukan tindakan balasan, malah mencercanya karena, menurutnya, rasa teh itu tidak sama seperti yang dulu dibuat Utari.

\section{"Terlalu manis!"}

Yang langsung dijawab Ningrum, "Tadi kurang manis, ya ditambahin gula. Sekarang malah terlalu manis."

"Ya nambahin gulanya kebanyakan. Utari aja kalau bikin teh selalu pas di lidah. Rasanya itu sepet-sepet manis. Nggak pernah kurang sedikit pun." (Virgiantini, 2020: hlm. 101)

Kutipan tersebut memperlihatkan bagaimana pun Ningrum berusaha untuk memenuhi konstruksi sosial tentang 'istri yang baik', rajin, dan patuh, ia tidak menerima bila dibandingkan dengan istri pertama suaminya. Harga dirinya sebagai perempuan dalam hal ini terusik.

Pada kondisi lain, sebagai perempuan dan istri yang menempati posisi objek, Ningrum juga merasa harus melapor pada subjeknya, Satria, jika ia akan pulang lebih larut malam dibanding biasanya. Situasi ini menurut Candraningrum (2015: hlm. 1) menunjukkan posisi perempuan yang sebelumnya sebagai manusia eksistensial yang independen kemudian direduksi menjadi makhluk yang dependen pada suami.

Seharusnya ia ngasih tahu kalau harus lembur sampai malam dan berlanjut nongkrong sama Padmi. [...]

Maaf, Mas, lupa ngabarin. Tadi lembur sampai isya terus lanjut nongkrong sama Padmi di roti bakar Simpang Lima.

(Virgiantini, 2020: hlm. 90)

Keharusan perempuan untuk selalu memberitahukan posisi dan kondisinya pada pasangan dalam konteks ini dapat dianggap sebagai objektifikasi karena kepemilikan menurut Nussbaum (2018). Bila tidak melakukannya, sang pemilik akan memeriksa dan mencari objek miliknya agar tidak rusak atau hilang. Selain itu, dalam relasi tersebut ditemukan adanya objektifikasi berupa penolakan subjektivitas, karena sebagai suami, Satria tidak membiarkan istrinya menjadi sosok yang mandiri dan bebas.

Dalam novel Perempuan Bayangan, terungkap bahwa objektifikasi perempuan yang pada umumnya dilakukan laki-laki, ternyata juga dapat dilakukan oleh sesama perempuan. Situasi ini terjadi misalnya ketika (arwah) Utari memanfaatkan Ningrum agar Satria mau merelakannya, sehingga ia dapat kembali bersama anaknya.

Ningrum menyadari perannya di rumah itu hanyalah sebatas figuran, atau peran pembantu yang kehadirannya hanya menegaskan keberadaan tokoh utama. Hampir setiap hari Satria terus menunjukkan hal-hal sentimental tentang almarhumah istrinya.

(Virgiantini, 2020: hlm. 124)

Sebagai sosok supranatural, Utari ditampilkan masih memiliki karakter manusia, yaitu agak cemburu melihat kedekatan Ningrum dan Satria. Ia juga gemar mengganggu Ningrum dengan cara meniup bulu kuduknya atau menggeser barang-barang. Hal ini memperlihatkan 
bahwa sosok Utari mengobjektifikasi Ningrum sebagai pengganti dirinya melayani Satria, serta sebagai sosok yang dapat ia permainkan selama merasa jenuh menjadi 'arwah penasaran'.

Dari pembahasan ini, diketahui bahwa tokoh Ningrum mengalami beragam objektifikasi yang dilakukan berbagai pihak sebagaimana yang telah diuraikan oleh Calogero (2012). Perempuan diobjektifikasi oleh orangtua yang memaksanya untuk menikah, oleh kedua calon mertuanya yang menolaknya karena tidak dapat memberikan keturunan, oleh pasangan yang memanfaatkannya untuk menghilangkan kesepian, dan oleh perempuan lain yang mengharapkan dirinya untuk menjadi pengganti. Bentukbentuk objektifikasi yang ditampilkan adalah fungsional, kepemilikan, penolakan subjektivitas, dan penolakan anatomi.

\section{Perlawanan Perempuan terhadap Objektifikasi}

Resiliensi, menurut Glicken (2018), merupakan kemampuan individu untuk bangkit dari suatu keterpurukan. Dalam konteks permasalahan yang dialami Ningrum, keterpurukan pertama berbentuk kesedihan karena tidak dapat membahagiakan kedua orangtuanya dengan cara menikah. Tindakan resilien yang pertama dilakukan oleh tokoh utama Ningrum terhadap objektifikasi dari lingkungannya adalah dengan menikahi Satria, meskipun tidak didasari rasa cinta. Hal ini ia lakukan selain untuk menyenangkan hati kedua orangtuanya, juga untuk membantah stigma yang dilekatkan oleh para calon mertuanya bahwa perempuan 'mandul' seperti dirinya tidak diinginkan oleh siapa pun.

"Dari pengalaman dua kali ditolak calon mertua ..." Ningrum diam sejenak. "Mungkin agak susah menemukan laki-laki yang mau menikah denganku."

(Virgiantini, 2020: hlm. 54)

Kesadaran akan tubuhnya membuat perempuan melakukan resistensi, sebagaimana dijelaskan oleh kajian Tyas (2018). Meskipun menyadari dirinya perempuan lajang yang telah berumur tiga puluh tahun dan tidak dapat memiliki anak, Ningrum memiliki estimasi diri yang cukup tinggi. Stereotipe yang dilekatkan masyarakat bahwa perempuan dengan kualifikasi tersebut akan pasrah menerima laki-laki manapun sebagai calon suami tidak terbukti. Ningrum tidak ingin diintimidasi oleh laki-laki yang dijodohkan oleh Padmi dengannya, Satria. Ia menunjukkan bahwa sebagai perempuan, dirinya memiliki hak untuk 'menilai' dan menyeleksi calon suaminya.

Secara langsung, perempuan ini pun dengan lantang mempertanyakan 'kejantanan' Satria yang telah lama menduda. Pertanyaan tentang seksualitas lawan jenis ini dalam kultur Timur akan dianggap 'saru' atau ganjil untuk ditanyakan, terlebih oleh perempuan pada laki-laki. Namun, Ningrum melakukan pendobrakan tatanan nilai tersebut dengan tujuan memastikan bahwa dirinya akan mendapatkan suami yang sehat secara jasmani.

"Maaf, sebagai laki-laki apakah Mas Satria masih normal?" tanya Ningrum tanpa malu-malu.

$A h$, sialan. Kenapa harus to the point begitu! Satria mengeluh sebal.

"Normal? Apa maksudmu?" Satria balik bertanya, meskipun sebenarnya sudah tahu maksudnya.

"Yah, saya pernah dengar kalau kesedihan yang sangat mendalam bisa membuat seorang laki-laki kehilangan kejantanannya," jawab Ningrum lugas.

(Virgiantini, 2020: hlm. 60) 
Menanggapi pertanyaan Ningrum tersebut, Satria merasa tidak nyaman karena otoritasnya sebagai laki-laki diragukan. Sebagai pihak dominan, ia menganggap pertanyaan dari pihak subordinat tersebut merendahkannya. Dengan keyakinan atas maskulinitasnya, Satria menjawab dalam hatinya "Langsung kita buktikan saja nanti!" (hlm.61). Tantangan tersebut semakin meyakinkannya untuk menikahi Ningrum.

Dengan tindakan simbolis, Ningrum menunjukkan perlawanan dengan cara meminum obat antimabuk yang membuatnya tertidur di malam pertama pernikahan. Tanpa seizin laki-laki itu, Ningrum pun menciumnya saat sedang tidur. Ningrum juga selalu bercanda ketika dibanding-bandingkan dengan Utari oleh Satria.

Namun, pada akhirnya, ia pun bangkit dari kondisinya yang tidak menentu dengan cara meninggalkan rumah saat merasa tidak dapat lagi menahan diri. Ningrum merasa sakit hati karena Satria dengan kata-kata pedas memarahinya, saat ia tidak sengaja memecahkan kaca pigura foto Utari. Kepergiannya ini menunjukkan bentuk resiliensi karena menjadi fase pemulihan dari kondisinya yang tersakiti selama berada di rumah Satria dan Utari. Ningrum keluar dari sistem opresi dan objektifikasi yang telah dibuat oleh Satria.

Melangkah meski terasa berat. Berjalan melewati Satria yang tengah berdiri di samping pintu. Pandangannya lurus ke depan dengan posisi kepala kaku. Raut mukanya menunjukkan rasa marah dan terluka. [...] Sekitar lima menit kemudian, Ningrum keluar kamar dengan tas ransel di punggung dan tas selempang di samping tubuhnya.

(Virgiantini, 2020: hlm. 161)
Saat Ningrum pergi, Satria baru menyadari bahwa ia membutuhkan perempuan itu. Jarak yang terentang di antara keduanya pun menyadarkan dirinya dan Ningrum bahwa mereka sebenarnya telah saling mencintai dan membutuhkan. Satria pun menyadari kesalahannya, mulai menyimpan foto-foto Utari dalam kotak, dan merelakan istrinya itu untuk pergi dan digantikan oleh Ningrum.

Sebagai sebuah metropop romance, maka novel Perempuan Bayangan ini harus ditutup dengan akhir yang bahagia. Kesan realistis dan kehadiran resiliensi yang paripurna sebenarnya akan tercipta, bila saja Ningrum tidak kembali pada Satria pada bab terakhir. Dalam pandangan Glicken, individu yang resilien memiliki kemampuan berkembang, menjadi dewasa, dan meningkatkan kompetensi diri dalam ruang lingkup yang tidak menguntungkan dirinya tersebut.

Pembahasan tentang resiliensi ini menunjukkan bahwa tokoh utama perempuan menunjukkan resiliensi atas kondisinya yang mengalami objektifikasi dari berbagai pihak. Ia memperlihatkan perilaku resilien, baik secara verbal maupun tindakan.

\section{PENUTUP}

Hasil penelitian ini menunjukkan bahwa perempuan rentan mengalami objektifikasi, sebagaimana yang diterima oleh Ningrum. Objektifikasi dilakukan oleh orangtua, kedua calon mertuanya, pasangan, dan arwah Utari. Tokoh utama perempuan kemudian menunjukkan resiliensi baik secara verbal maupun dalam bentuk tindakan. Objektifikasi yang dialami tokoh perempuan menunjukkan bahwa perempuan masih dianggap sebagai objek, baik disadari ataupun tidak, dan laki-laki sebagai subjek. Resiliensi yang ditunjukkan perempuan merupakan bentuk perlawanan, namun tidak dapat dinilai memadai karena tidak sepenuhnya mengubah hakikat objektifikasi yang telah 
terjadi. Pembebasan perempuan dari objektifikasi hanya dapat dilakukan melalui penghancuran ideologi patriarki yang menjadi gagasan residual di dalam novel karya Netty Virgiantini ini.

Penelitian terhadap novel Perempuan Bayangan maupun karya-karya Netty Virgiantini masih dapat dilanjutkan, karena masih banyak celah dan permasalahan yang dapat dipelajari. Pendekatan lain pun dapat digunakan untuk mengupas karya-karya kontemporer penulis perempuan seperti dengan sosiologi sastra, antropologi sastra, maupun psikologi sastra.

\section{DAFTAR PUSTAKA}

Ariadi, C. N. (2019). Peran Tokoh Perempuan dalam Novel-novel Karya Ratih Kumala. Skriptorium, 8(1), 114-125.

Ariawan, R. E. (2019). Opresi dan Objektifikasi terhadap Perempuan dalam Film Pendek Libertines Karya Arwin Wardhana: Sebuah Kajian Feminis Radikal Libertarian. Humanika, 1-11.

Artana, F. K. W. (2018). The Woman Objectification and Abjection in Hannah Kent's Burial Rites. Language Horizon, 6(1), 74-84.

Budiarti, Y. O. (2014). Resistensi dari Objektifikasi Terhadap Perempuan Dalam Novel The Sinden Karya Halimah Munawir. (Skripsi), Universitas Diponegoro, Semarang.

Calogero, R. (2012). Objectification Theory, Self-Objectification, and Body Image. Encyclopedia of Body Image and Human Appearance 2, 24, 574-580.

Candraningrum, D. (2015). Negara, Seksualitas dan Pembajakan Narasi Ibu. Forum Kajian Antropologi Indonesia. Paper presented at the Narkoba, Seksualitas dan Politik, Depok.
Deborah, S. d. (2018). Trauma dan Resiliensi pada Wanita Penyintas Kekerasan dalam Rumah Tangga. Jurnal Ilmiah Psikologi MANASA, 7(2), 121-130.

Djajanegara, S. (2003). Kritik Sastra Feminis: Sebuah Pengantar. Jakarta: Gramedia Pustaka Utama. Intan, T. (2021). Perempuan Lajang dan Perjodohan dalam Novel Jodoh Terakhir Karya Netty Virgiantini. Alinea: Jurnal Bahasa Sastra dan Pengajaran, 10(1), 1-14.

Intan, T., Elga Ahmad Prayoga. (2021). Strategi Kebertahanan Perempuan Lajang dalam Novel Cincin Separuh Hati Karya Netty Virgiantini. Fonema: Edukasi Bahasa dan Sastra Indonesia, 4(1), 1-17. Intan, T. G., Trisna. (2020). Perempuan Bersampur Merah Karya Intan Andaru: Resiliensi Perempuan Terhadap Stigma dan Trauma. Linguista: Jurnal Ilmiah Bahasa, Sastra, dan Pembelajarannya, 4(1), 9-21.

Lahdji, R. F. (2015). Objektifikasi

Perempuan dan Tubuh: Wacana

Tubuh Perempuan dalam Lirik Lagu Dangdut Populer Tahun 2000-2013. Lakon, 4(1), 103-130.

Normuliati, S. U., Nida. (2015). Eksistensi Perempuan dalam Novel Cincin Separuh Hati Karya Netty Virgiantini. Jurnal Paradigma, 10(2), 19-24.

Nurfaidah, R. (2018). Membaca Perempuan dalam Celoteh Perempuan. Metasastra, 11(2), 157168.

Pratiwi, A. C. H. (2016). Hubungan

Coping dan Resiliensi pada Perempuan Kepala Rumah Tangga Miskin. Jurnal Psikologi, 12(2), 6873.

Schoon, I. (2006). Risk and Resilience Adaptations in Changing Times. USA: Cambridge University Press. 
Sastra Indonesia

FKIP Universitas Kuningan

Tyas, U. N. W. (2018). Perlawanan atas Kekuasaan dan Objektivikasi Perempuan Kajian Feminis Radikal Kultural terhadap Cerita Cinta Enrico karya Ayu Utami. (Skripsi), Universitas Diponegoro, Semarang. Virgiantini, N. (2015). Cinta Separuh Hati. Jakarta: PT Gramedia Pustaka Utama.

Virgiantini, N. (2016). Jodoh terakhir. Jakarta: PT Gramedia Pustaka Utama.
Virgiantini, N. (2020). Perempuan Bayangan. Jakarta: PT Gramedia Pustaka Utama.

Walby, S. (2014). Teorisasi Patriarki (M. K. Prasela, Trans.). Yogyakarta: Jalasutra.

Windiyarti, D. (2017). Novel Gadis Pantai karya Pramoedya Ananta Toer:

Objektivikasi Perempuan oleh Lakilaki. Semiotika, 18(1), 1-13.

Wiyatmi. (2012). Kritik Sastra Feminis:

Teori dan Aplikasinya dalam Sastra. Yogyakarta: Ombak. 